\title{
Pollutants harmful to health in herbal products detected by X-ray fluorescence spectroscopy
}

\section{Poluentes prejudiciais à saúde em produtos à base de plantas detectados pela espectroscopia de fluorescência de raios-X}

\author{
Thais Hora Paulino Estanagel ${ }^{1}$; Valquíria Miwa Hanai-Yoshida ${ }^{2}$; \\ Cristiane Renata Gaiotto Caldana ${ }^{3}$; Waldemar Bonventi Junior ${ }^{4}$; \\ Marco Vinicius Chaud ${ }^{5}$; Norberto Aranha ${ }^{6}$; Marta Maria Duarte Carvalho Vila ${ }^{7}$; \\ Victor Manuel Cardoso Figueiredo Balcão ${ }^{8}$; José Martins de Oliveira Junior ${ }^{9}$
}

\begin{abstract}
The goal of this research was to evaluate the chemical composition of some herbal products consumed in Brazil through the Energy Dispersive X-ray Fluorescence (EDXRF). The methodology used encompassed the selection of 14 plants' dried extracts and six ground plants. The qualitative and quantitative analyses of samples indicating the presence of $\mathrm{As}, \mathrm{Cr}, \mathrm{Cu}, \mathrm{Fe}, \mathrm{Ni}, \mathrm{Zn}, \mathrm{Si}, \mathrm{P}, \mathrm{S}, \mathrm{Cl}, \mathrm{K}, \mathrm{Ca}, \mathrm{Ti}, \mathrm{V}, \mathrm{Mn}, \mathrm{Co}, \mathrm{Rb}, \mathrm{Zr}, \mathrm{Cd}, \mathrm{Sn}$, $\mathrm{Ba}, \mathrm{Hg}, \mathrm{Pb}, \mathrm{Bi}, \mathrm{Mo}$, and $\mathrm{Pt}$ in different concentrations. It is feasible that part of the contamination found in the herbal products come from the adjuvants/excipients used in the production process. Also, it was found that the extract production process seems to have a low efficiency for the extraction of the main chemical elements present in the ground plants. In the other hand, it has the benefit of reducing the contamination by harmful elements to health, such as heavy metals. EDXRF can replace atomic absorption spectrometry as low-cost and high precision technique to quantify all elements of interest in the pharmaceutical and food industries, within the limits established by regulatory agencies.
\end{abstract}

Keywords: Plant products. Energy dispersive X-ray fluorescence (EDXRF). Dried extracts. Ground medicinal plant. Heavy metal contamination.

\section{Resumo}

O objetivo desta pesquisa foi avaliar a composição química de alguns produtos à base de plantas consumidos no Brasil por meio da Fluorescência de raios-X por energia dispersiva (EDXRF). A metodologia utilizada abrangeu a seleção de 14 extratos secos de plantas e seis plantas moídas. As análises qualitativas e quantitativas das amostras indicando a presença de As, Cr, Fe, Ni, Zn, Si, P, S, Cl, K, Ca, Ti, V, Mn, Co, Rb, Zr, Cd, Sn, $\mathrm{Ba}, \mathrm{Hg}, \mathrm{Pb}, \mathrm{Bi}$, Mo e Pt em diferentes concentrações. Parte da contaminação encontrada nos produtos à base de plantas pode ser originária dos adjuvantes/excipientes utilizados no processo de produção. Além disso, constatou-se que o processo de produção do extrato parece ter baixa eficiência para a extração dos principais elementos químicos presentes nas plantas moídas. Por outro lado, tem o benefício de reduzir a contaminação por elementos nocivos à saúde, tais como metais pesados. A EDXRF pode substituir a espectrometria de absorção atômica como técnica de baixo custo e alta precisão para quantificar todos os elementos de interesse nas indústrias farmacêutica e alimentícia, dentro dos limites estabelecidos pelas agências reguladoras.

Palavras-chave: Produtos de plantas. Fluorescência de raios-X por energia dispersiva (EDXRF). Extratos secos. Planta medicinal moída. Contaminação por metais pesados.

\footnotetext{
${ }^{1}$ Doutoranda no PPGCF, UNISO, Sorocaba, SP, Brazil; E-mail:thaishpaulino@hotmail.com

2 Profa. Dra., Dpto. de Ciências Farmacêuticas, PPGPTA, UNISO, Sorocaba, SP, Brazil; E-mail:valquiria.yoshida@prof.uniso.br

${ }^{3}$ Mestranda no PPGTA, UNISO, Sorocaba, SP, Brazil; E-mail:gaiottocristiane@gmail.com

${ }^{4}$ Prof. Dr., Dpto. de Computação, FATEC, Sorocaba, SP, Brazil; E-mail: waldemar.junior@ fatec.sp.gov.br

${ }^{5}$ Prof. Dr., Dpto. de Ciências Farmacêuticas, PPGCF e PPGPTA, UNISO, Sorocaba, SP, Brazil; E-mail:marco.chaud@prof.uniso.br

${ }^{6}$ Prof. Dr., Dpto. de Física, PPGPTA, UNISO, Sorocaba, SP, Brazil; E-mail:norberto.aranha@ prof.uniso.br

${ }^{7}$ Profa. Dra., Dpto. de Química, PPGCF e PPGPTA, UNISO, Sorocaba, SP, Brazil; E-mail:marta.vila@ prof.uniso.br

8 Prof. Dr., Dpto. de Biotecnologia, PPGCF and PPGPTA, UNISO, Sorocaba, SP, Brazil; E-mail:victor.balcao@ prof.uniso.br

${ }^{9}$ Prof. Dr., Dpto. de Física, PPGCF and PPGPTA, UNISO, Sorocaba, SP, Brazil; E-mail: jose.oliveira@ prof.uniso.br
} 


\section{Introduction}

From the beginning of medical history to the present day, plant medicines represent a regular part of medical treatment and health maintenance. Medicinal plants extract, as well as, medicinal plants, crushed, milled or in the form of powder, are used in different areas, such as pharmaceutical, cosmetic and food, being used in different applications and pharmaceutical forms. Additional factors that promote the consumption of plant-based products are based on the belief that these are natural and "natural is good" and therefore safe (ABDEL-TAWAB, 2018). However, few studies report the chemical composition of plants and their extracts and whether they contain substances harmful to the human health, since these products are widely used in foods, beverages and medicinal preparations (MARGUÍ; QUERALT; HIDALGO, 2009).

The use of medicinal plants for treatment, cure, and prevention of diseases is one of the oldest forms of human practice (SANTOS et al., 2017). The common misconception that botanical products are harmless and devoid of adverse effects often lead to misuse and unrestricted ingestion, resulting in an increased incidence of side effects and drug interactions (ABDEL-TAWAB, 2018).

Phytomedications are classified as nutritional supplements based on medicinal herbs and are an important source of nutrients (vitamins, minerals and amino acids) (SANTOS et al., 2017), therefore, scientific studies involving medicinal plants are justified in order to verify their chemical composition and to evaluate their medicinal properties (EKINCI et al., 2004).

Quality standards for plant medicines have evolved significantly in the last decades (LÄNGER et al., 2017), since chemical elements with toxic properties are harmful to the human body, even in very low concentrations (AL-OMARI, 2011). When in small amounts they are necessary to maintain good health, but the presence beyond certain thresholds tends to be harmful, causing acute or chronic intoxication (NKANSAH et al., 2016; JAISHANKAR et al., 2014), that is, in small quantities some are needed to maintain good health but in higher amounts they can become toxic or dangerous. The toxicity of heavy metals can impair the functioning of the brain, lungs, kidney, liver and other important organs, as well as impact negatively on blood composition (JAISHANKAR et al., 2014).

The knowledge of the elemental composition of herbal medicines is very important in the determination of their toxicity and, consequently, in assessing their safety for use (NKANSAH et al., 2016; OBIAJUNWA; ADEBAJO; OMOBUWAJO, 2002). Therefore, the concentration of some chemical elements is one of the criteria that make natural plants admissible for human consumption (MARGUÍ; QUERALT; HIDALGO, 2009). The metals levels are important in herbal medicines due to their toxicological properties as well as from a nutritional point of view (SANTOS et al., 2017). This scenario has contributed to the search for analytical tools to determine the chemical elemental composition of herbal products. Exposure to heavy metals in the long term can lead to degenerative processes that cause diseases such as multiple sclerosis, Parkinson's disease, Alzheimer's disease and muscular dystrophy (JAISHANKAR et al., 2014), indicating once again the need to investigate the chemical composition of herbal products in order to evaluate more accurately the presence of chemical elements harmful to health, even in low concentrations, or the absence of essential ones for the proper functioning of the metabolism of living beings. Only reliable analyses will help to clarify and define the most effective treatment and toxic levels for a living being (EKINCI et al., 2004).

The plants origin and the methods used to obtain their extracts will define the final product physicochemical characteristics. It is necessary to investigate the chemical composition of these extracts to avoid the presence of contaminants harmful to the health, since heavy metals are highly harmful to the health of living beings even in low concentrations.

The EDXRF technique has been used in the determination of the chemical elemental composition of all kind of material, like cement (MENNA JUNIOR et al., 2020), in cosmetic products (MOLARI et al., 2019; SANTOS et al., 2018), metal monitoring in water from lakes and rivers (MELQUIADES et al., 2008) among others. EDXRF has been used also in study of plants extracts in several parts of the word, as shown in the work of Obiajunwa, Adebajo and Omobuwajo (2002), which determined the chemical elemental composition of trace elements of about 20 Nigerian medicinal plants, in the work of Ivanova, Djingova and Kuleff (1998), which used the EDXRF technique for the analysis of soils and medicinal plants of Bulgaria, in the work of Marguí, Hidalgo and Queralt (2005), using EDXRF to determine the contents of macro and microelements in bulk products of five plants commonly used in Spain; in the work of Al-Omari (2011), which analyzed the elemental concentration of ten drugs purchased on the market in Jordan, where the concentrations of 19 chemical elements were analyzed and, more recently, in the works 
of McGladdery and coworkers (2018), who used EDXRF to analyze the elemental composition of organic material of 228 samples of plants, involving straw, leaves and bark acquired in the Romanian market and the work of Luiz and coworkers (2019), who did a qualitative study of five medicinal plants commercialized in the state of Rio de Janeiro (RJ, Brazil) using X-ray Fluorescence analysis. A large compilation of data pertaining to herbal products can be found in the work of Sarma et al. (2011).

\section{Material and Methods}

\section{Plant products and their adjuvants}

Fourteen dried extracts of medicinal plants, six samples of ground medicinal plants and four adjuvants and/or excipients were used in the analyses undertaken. Two types of Camellia sinensis L. were studied, because the matcha type according to Yamabe et al. (2009) is richer in some nutritional elements and epigallocatechin 3-Ogallate than other green teas. The dried extracts and ground plants were purchased in the Brazilian market. The specifications of use or therapeutics indications, common and scientific names, and parts of the plants used in the preparations, sample type (and coding in this work) are described in Table 1.

The process of manufacturing the ground plants follows the steps:

(i) the plants are received and pass through an evaluation of their organoleptic characteristics and in case of approval by the quality control, they are sent to the storage area for later grinding;

(ii) after the production order is issued, the plants enter the grinding process, which consists in placing the plants in an iron hammer mill, with a specific sieve for powder granulometry;

(iii) the resulting milled material is irradiated with gamma-rays to eliminate any possible microorganisms present, is then sent to the quality control laboratory for physicochemical and microbiological analyzes.

In this study the dried extracts were obtained via spray drying atomization manufacturing method following the steps:

(i) plants were received and passed through an evaluation of their organoleptic characteristics and, in case of approval by the quality control, they are sent to the storage area for later grinding; (ii) after the production order is issued, plants enter in the grinding process, which consists in placing the plants in an iron hammer mill, with specific sieve for ripped or ground granulometry;

(iii) after the grinding process, plants go to the extraction tank to produce the concentrate. Production of the concentrated extract consists of adding the solvents (water and/or alcohol) to the crushing plant for extraction, as well as the preservatives used. The extraction process was carried using either hot or cold conditions and the extraction time varied according to the plant used. The concentrated extract was sent to the quality control laboratory for the appropriate physicochemical and microbiological analyses and, in case of approval, was released to the drying process;

(iv) concentrated extract was sent to the mixing and stirring tank, and excipients and/or adjuvants (such as corn starch, maltodextrin, silicon dioxide, and dyes) may be added to the concentrate when necessary. The resulting extract was sent by the controlled speed pump to the spray dryer. Dried extract, after leaving spray dryer, passed through a vibrating sieve to standardize the granulometry. After drying, a sample was withdrawn and sent to physicochemical and microbiological analyses.

\section{EDXRF system and experimental setup}

The Energy Dispersion X-ray Fluorescence (EDXRF) analysis is a multi-elemental analysis technique, which consists in the spectrophotometric measuring of the characteristic X-rays resulting from the excitation of the atoms of a sample. This qualitative and quantitative technique allows to identify and establish the proportion of the chemical elements present in a sample, from the lightest chemical elements, such as, Al to the heavier ones like Fm, simultaneously, in a fast way, with minimal preparation of the samples, in concentrations that may range from a few $\mu \mathrm{g} \mathrm{g}^{-1}$ to thousands of $\mu \mathrm{g} \mathrm{g}^{-1}$, in a nondestructive fashion (MENNA JUNIOR et al., 2020; SANTOS et al., 2018).

The laboratory setup used in this research effort comprised a compact system, marketed by Amptek (Bedford, Massachusetts, USA), composed of a silicon detector (Silicon Drift Diode) with $25 \mathrm{~mm}^{2}$ of the area by $500 \mu \mathrm{m}$ of thickness, protected by a beryllium window of $12.5 \mu \mathrm{m}$. 
Table 1 - Scientific name, common name in Brazil, part of the plant used in the analyses, therapeutic indication and type of samples analyzed.

\begin{tabular}{|c|c|c|c|}
\hline $\begin{array}{l}\begin{array}{l}\text { Scientific name } \\
\text { (common name) }\end{array} \\
\end{array}$ & Used part & Therapeutic indication & Sample type (code) \\
\hline $\begin{array}{l}\text { Aesculus hippocastanum } \mathrm{L} . \\
\text { (Castanha da Índia) }\end{array}$ & Seed & $\begin{array}{l}\text { Anti-inflammatory } \\
\text { (SIMÕES, 2003) }\end{array}$ & Dried extract (CtE) \\
\hline $\begin{array}{l}\text { Camellia sinensis } \mathrm{L} . \\
\text { (Chá verde) }\end{array}$ & Leaf & $\begin{array}{l}\text { Antioxidant, anti-inflammatory,stimulant, } \\
\text { angioprotective and anti-free radicals } \\
\text { (SIMÕES, 2003) }\end{array}$ & $\begin{array}{l}\text { Dried extract (ChE) and } \\
\text { ground plant (ChM) }\end{array}$ \\
\hline $\begin{array}{l}\text { Camellia sinensis } \mathrm{L} . \\
\text { (Matcha) }\end{array}$ & Leaf & $\begin{array}{l}\text { Antioxidant, anti-inflammatory, stimulant, } \\
\text { angioprotective and anti-free radicals } \\
\text { (SIMÕES, 2003) } \\
\text { and beneficial effects on renal and hepatic damage } \\
\text { (YAMABE } \text { et al., 2009) }\end{array}$ & Dried extract (MxE) \\
\hline $\begin{array}{l}\text { Cynara scolymus } \mathrm{L} \text {. } \\
\text { (Alcachofra) }\end{array}$ & Leaf & $\begin{array}{c}\text { Antidyspeptic } \\
\text { (ANVISA, 2011), } \\
\text { prevention of hepatotoxicity, appetite } \\
\text { stimulant, laxative and diuretic } \\
\text { (SAAD } \text { et al., 2016) }\end{array}$ & $\begin{array}{l}\text { Dried extract (AfE) and } \\
\text { ground plant (AfM) }\end{array}$ \\
\hline $\begin{array}{l}\text { Echinacea purpurea } \mathrm{L} . \\
\text { (Equinácea) }\end{array}$ & Leaf & $\begin{array}{l}\text { Aerial part Immunostimulant, treatment of } \\
\text { acute respiratory tract infections } \\
\text { (BARRETT, 2003) }\end{array}$ & $\begin{array}{l}\text { Dried extract }(\mathrm{EqE}) \text { and } \\
\text { ground plant }(\mathrm{EqM})\end{array}$ \\
\hline $\begin{array}{l}\text { Ilex paraguariensis } \\
\text { (Mate verde) }\end{array}$ & Leaf & $\begin{array}{l}\text { Anti-inflammatory, } \\
\text { antioxidant and stimulant } \\
\text { (SIMÕES, 2003) }\end{array}$ & Dried extract (MtE) \\
\hline $\begin{array}{l}\text { Malpighia glabra L. } \\
\text { (Acerola) }\end{array}$ & Fruit & $\begin{array}{l}\text { Antioxidant, treatment of anemia } \\
\quad \text { (FREITAS } \text { et al., 2006) }\end{array}$ & Dried extract (AcE) \\
\hline $\begin{array}{l}\text { Maytenus ilicifolia } \mathrm{L} . \\
\text { (Espinheira santa) }\end{array}$ & Leaf & $\begin{array}{l}\text { Antidyspeptic, antacid and } \\
\text { protector of the gastric mucosa } \\
\text { (ANVISA, 2011) }\end{array}$ & $\begin{array}{l}\text { Dried extract (EsE) and } \\
\text { ground plant (EsM) }\end{array}$ \\
\hline $\begin{array}{l}\text { Melissa officinalis L. } \\
\text { (Melissa) }\end{array}$ & Leaf & $\begin{array}{l}\text { Antispasmodic, anxiolytic and } \\
\text { mild sedative } \\
\text { (ANVISA, 2011) }\end{array}$ & Dried extract (MeE) \\
\hline $\begin{array}{l}\text { Myrciaria dubia } \\
\text { (Camu-camu) }\end{array}$ & Fruit & $\begin{array}{c}\text { Antioxidant } \\
\text { (AZEVEDO, 2015) }\end{array}$ & Dried extract $(\mathrm{CaE})$ \\
\hline $\begin{array}{l}\text { Passiflora incarnata } \mathrm{L} . \\
\text { (Passiflora) }\end{array}$ & Leaf & $\begin{array}{l}\text { Aerial part Sedative, } \\
\text { antispasmodic and anxiolytic } \\
\text { (SIMÕES, 2003) }\end{array}$ & Dried extract $(\mathrm{CaE})$ \\
\hline $\begin{array}{l}\text { Paullinia cupana } \mathrm{K} . \\
\text { (Guaraná) }\end{array}$ & Seed & $\begin{array}{c}\text { Stimulant } \\
\text { (SIMÕES, 2003) }\end{array}$ & $\begin{array}{l}\text { Dried extract }(\mathrm{GuE}) \text { and } \\
\text { ground plant }(\mathrm{GuM})\end{array}$ \\
\hline $\begin{array}{l}\text { Rhamnus purshiana } \\
\text { (Cáscara sagrada) }\end{array}$ & Leaf & $\begin{array}{l}\text { Stem' shell Soft laxative } \\
\text { (SIMÕES, 2003) }\end{array}$ & $\begin{array}{l}\text { Dried extract }(\mathrm{CsE}) \text { and } \\
\text { ground plant }(\mathrm{CsM})\end{array}$ \\
\hline $\begin{array}{l}\text { Solanum sessiliflorum } \\
\text { (Fruit) }\end{array}$ & Leaf & $\begin{array}{c}\text { Antioxidant } \\
\text { (SERENO } \text { et al., 2017) }\end{array}$ & Dried extract $(\mathrm{MaE})$ \\
\hline
\end{tabular}

Source: The authors.

The source of X-rays used for excitation of the samples consisted of a miniature X-ray tube with an Ag anode, marketed by Amptek (Bedford, Massachusetts, USA). The $\mathrm{X}$-ray tube was set up to work at $30 \mathrm{kV}$ and $10 \mu \mathrm{A}$. The energy resolution of the detection system is $125 \mathrm{eV}$ quoted as the full width at half maximum (FWHM) for Mn of $\mathrm{K} \alpha 5.9 \mathrm{keV}$ X-rays from a ${ }^{55} \mathrm{Fe}$ source. All measurements were carried out using atmospheric air, and the measuring time was set at $300 \mathrm{~s}$ (live time) for each sample. A collimator with an aperture of $2 \mathrm{~mm}$ was used at the exit of the X-ray source. Additionally, Amptek's ADMCA software for data acquisition and control of the signal processor and Amptek's XRS-FP ${ }^{\mathrm{TM}}$ software for spectrum pro- cessing and quantitative analysis were used. The EDXRF system was calibrated using control samples.

\section{Calibration of the fluorescence system}

The calibration of the fluorescence system is of paramount importance for the correct quantification of the chemical elements of interest, especially for those elements that should appear in low concentrations, such as heavy metals. Primary standard as a function of the number of counts and their respective linear fitting curves were made for all elements analyzed in this study. The calibration curves for heavy metals $\mathrm{Hg}, \mathrm{Pb}$, As and $\mathrm{Cd}$ are shown in Figures 1, 2, 3 and 4, respectively. 
Figure 1 - The ordinates axis is the concentration of $\mathrm{Hg}$ used in the calibration process and the abscissa axis is the number of characteristic X-rays that reached the detector. The calibration curve $(Y=2.84 x-9.16)$ has a coefficient of determination $\mathrm{R}^{2}=0.9974$.

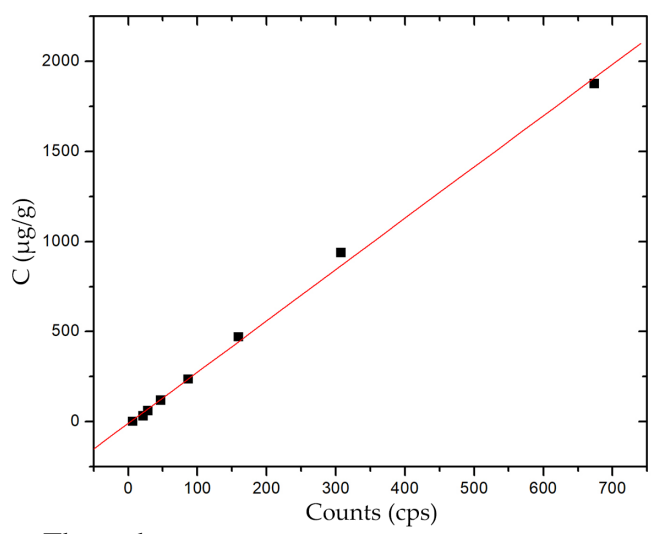

Source: The authors.

Figure 2 - The ordinates axis is the concentration of $\mathrm{Pb}$ used in the calibration process and the abscissa axis is the number of characteristic $X$-rays that reached the detector. The calibration curve $(Y=3.35 x-7.89)$ has a coefficient of determination $\mathrm{R}^{2}=0.9945$.

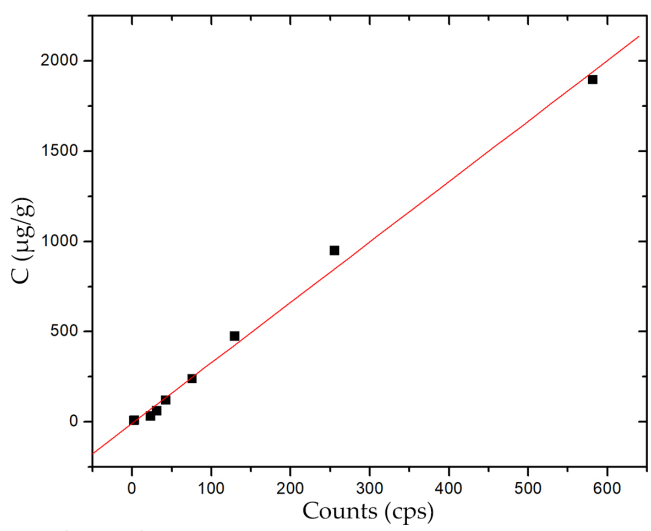

Source: The authors.

Figure 3 - The ordinates axis is the concentration of As used in the calibration process and the abscissa axis is the number of characteristic X-rays that reached the detector. The calibration curve $(Y=1.18 x-30.74)$ has a coefficient of determination $\mathrm{R}^{2}=0.9997$.

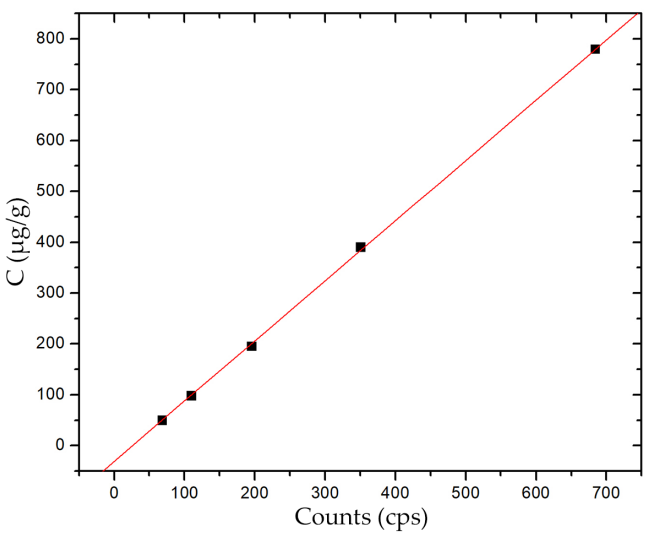

Source: The authors.
Figure 4 - The ordinates axis is the concentration of $\mathrm{Cd}$ used in the calibration process and the abscissa axis is the number of characteristic X-rays that reached the detector. The calibration curve $(Y=219.12 x-5.71)$ has a coefficient of determination $\mathrm{R}^{2}=0.9849$.

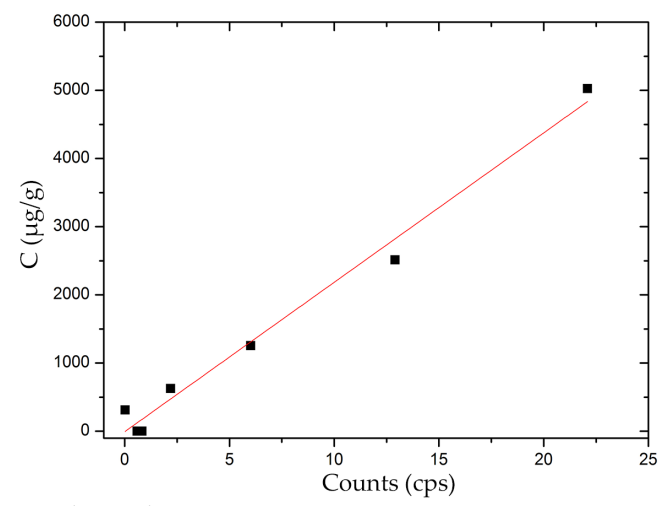

Source: The authors.

The calibration should be done using known quantities of target elements, inserted in a matrix like the one that will be used in the measurements. In this research work we used a press of 15 ton to produce tablets of the dried extracts and medicinal ground plants, which were then analyzed by the fluorescence system. Hence, to calibrate the fluorescence system one produced pellets with reference materials, diluted in an organic base used as additive, composed basically of $\mathrm{C}$ and $\mathrm{H}$ atoms, having in lower proportion $\mathrm{O}$ and $\mathrm{N}$ (PREMIER LAB SUPPLY, 2019), with the following chemical formula $\mathrm{C}_{38} \mathrm{H}_{76} \mathrm{O}_{2} \mathrm{~N}_{2}$, marketed by Premier LabSupply. Each pellet was made up of $3 \mathrm{~g}$ of material (analyte plus additive), being subjected to a compression machine applying 15 ton of pressure for a time of $60 \mathrm{~s}$, producing tablets with a diameter of $22 \mathrm{~mm}$ by $3 \mathrm{~mm}$ of height.

The analytes used as reference material in the manufacture of the tablets for calibrating the fluorescence system were purchased from the company Chemplex Industries Inc. (SpectroStandards $₫$ XRF reference material preparation kit number 6700). The kit contains 50 different chemical elements, most of which are oxide-based.

Calibration tablets were made using different concentrations of analyte.

Using the calibration curves and the analysis of the signal-to-noise ratio at low analyte concentrations, it was possible to estimate the detection limit for most of the elements studied in this work and for the heavy metals $\mathrm{Hg}$, $\mathrm{Pb}, \mathrm{As}$ and $\mathrm{Cd}$ the estimated value was around $2 \mu \mathrm{g} \mathrm{g}^{-1}$, therefore, all elementary concentrations presented in this work, less than $2 \mu \mathrm{g} \mathrm{g}^{-1}$, should be interpreted as a residual or trace concentration of the element in question. 


\section{Cluster analysis}

Cluster analysis consists of trying to subdivide objects into clusters in such a way that objects with similar attributes are close together in some suitable graphical representation space. In this space, one can then perceive the formation of groups, with a reasonably clear separation from each other. In this subdivision process, the distances between the objects of the same group should be the smallest possible, compared to the distances between objects of different groups. These distances must be defined from the measures of the attributes, establishing how much the set of attributes is different in each object.

The representation spaces typically used are bi or threedimensional graphics for two or three attributes and dendrograms for three or more attributes. In graphics, each object appears as a point. Dendrograms are tree-shaped representations where each terminal or leaf represents an object and the branches represent the groups.

One way to compare objects that have $\mathrm{N}$ characteristics is to perform clustering analysis. Very similar objects have few differences in these $\mathrm{N}$ characteristics. The similarity between objects can be measured as a "distance between object data". Among the various measures, Euclidean and correlation are frequently used. Also, such data distances in clusters are always evaluated between pairs of objects (THEODORIDIS; KOUTROUMBAS, 2009).

One way to plot these distances or correlation relationships is through the dendrogram, where each bifurcation is at the level of distance or correlation that separates two objects (at the first level) and at other levels, the bifurcations express the distances between the centers of the groups. The dendrogram is constructed hierarchically, by means of successive agglutinations of objects, with the measurement of distance or correlation with each agglutination performed (JAIN; DUBES, 1988).

The software used in cluster analysis performed in this study was PaSt (Paleontological Statistics) (HAMMER et al., 2001). The dendrograms and clustering maps of the samples were made using Python software, the Seaborn data analysis library and the Matplotlib graphic library (MCKINNEY, 2013).

\section{Principal component analysis}

Principal Component Analysis (PCA) seeks to reduce the dimensionality of data by expressing them in terms of new variables called components, that are linear combinations of the original variables. These components are calculated in a hierarchical way, that is, in decreasing or- der of information that each can cover over the data set. If original variables are highly correlated, then they carry the same information, that is, there is substantial redundancy. Using the dimensionality reduction provided by the main components (which retain most of the information) the data analysis becomes more facilitated to the researcher. Consequently, there is a balance between simplicity and objectivity (fewer major components) and richness and detail of the information obtained (using more components).

The main components are variables produced as linear combinations of the original variables in order of the information significance. The first major component contains the largest variance amongst the original variables. If the data are bivariate, this main component has an axis oriented along the largest axis defined by the distribution of the data in the two-dimensional space, the same occurring for larger dimensions.

The second major component defines an orthogonal axis to the first so that the remaining variance is still as large as possible. And so on for the other components. As a result, due to the orthogonality obtained, the principal components are mutually uncorrelated and each one explains the largest possible amount of variation not yet explained by the previous components (hierarchically above it).

In an analysis of principal components, the grouping of the samples defines the structure of the data through graphs of scores and loadings. In these charts, the axes are the principal components (PCs).

The scores provide the composition of the PCs in relation to the samples and are calculated as the projections of the attributes in the new axes of the PCs. The loadings inform the composition of the PCs in relation to the variables, is calculated by the cosine of the angle between the axis of each variable and the axis of each PC. Thus, it is possible to examine the relationships between samples and variables through such graphs, thanks to the orthogonality of PCs. This joint study allows us to observe the influence of each variable in each sample. The software used for principal component analysis was also the PaSt (Paleontological Statistics) (HAMMER et al., 2001). As in cluster analysis, the raw data is selected and the software allows the selection of the PCA with the generation of screes, scores, and loadings.

PCA was performed considering the occurrence of chemical elements as the target objects of this study, so that the relationship between these elements and the CPs were interpreted as scores as well as the relationship between plants and CPs as loadings. 


\section{Results and Discussion}

\section{EDXRF analytical curve}

The qualitative and quantitative elemental analyses performed in this work, using the EDXRF, showed the presence of the chemical elements $\mathrm{As}, \mathrm{Cr}, \mathrm{Cu}, \mathrm{Fe}, \mathrm{Ni}, \mathrm{Zn}$, Si, P, S, Cl, K, Ca, Ti, V, Mn, Co, Rb, Zr, Cd, Sn, Ba, Hg, $\mathrm{Pb}, \mathrm{Bi}, \mathrm{Mo}$ and $\mathrm{Pt}$ in ground plants, extracts of medicinal plants and some adjuvants used in their manufacture process.

Analyzing the calibration curves obtained in this work, it was possible to estimate the limit of detection, staying around $2 \mu \mathrm{g} \mathrm{g}^{-1}$, for heavy metals, showing high sensitivity of the system for detection of these elements, which usually appear in low concentrations.

The linear fitting performed to the experimental data points exhibited a coefficient of determination, $\mathrm{R}^{2}$, very close to unity, except for the $\mathrm{Cd}\left(\mathrm{R}^{2}=0.9849\right)$ element, indicating a good precision in the quantification of these elements. Concentrations below $2 \mu \mathrm{g} \mathrm{g}^{-1}$, should only be interpreted as a residual or trace of the presence of the element in question.

\section{EDXRF results}

The EDXRF analyses were carried out in triplicate, and the results are presented as average values of the concentrations and associated standard deviations. Table 2 displays the chemical elements identified and quantified in the dried extracts of samples 1 to 7 of medicinal plants and Table 3 (continuation of Table 2) displays the same results for samples 8 to 14 of medicinal plants. Table 4 shows the chemical elements identified and quantified (samples 15 to 20 of medicinal plants) for the ground medicinal plants. Concentrations and associated errors are presented in $\mu \mathrm{g} \mathrm{g}^{-1}$, (ppm).

The data presented in Tables 2, 3 and 4 were originally published in the proceedings of the XLI Brazilian Meeting on Nuclear Physics (ESTANAGEL et al., 2019). The results obtained in the present research work show that for both type of products, dried extracts of the medicinal plants and ground medicinal plants, a huge range of chemical elements could be identified and quantified, that is, something around 26 elements appear in almost all the samples analyzed.

To improve the manufacturing process used in the production of the dried extracts, in some cases the use of adjuvants is necessary, for example, to reduce the humidity of the dried extract, preventing it from accumulating on the walls of the equipment components or to improve its appearance, color, etc. Table 5 shows the chemical elements identified and quantified in the adjuvants used in the manufacturing process. Table 5 also shows that the use of adjuvants and/or excipients in the manufacturing process introduces contaminants into the dried extracts of medicinal plants or add elements that were not originally present, such as the Si element which, due to the use of the substance silicon dioxide as secant, was introduced into some dried extracts, as can be seen when comparing the dried extract of $C$. sinensis L. with the value obtained for the ground plant, where this element was not originally present. The use of adjuvants also introduces harmful contaminants to the health of living beings, such as the heavy metals $\mathrm{Hg}, \mathrm{Pb}, \mathrm{As}$, and $\mathrm{Cd}$. As shown in Table 5, for example, for $\mathrm{Cd}$, where a high concentration of this element was detected in the caramel dye, and $\mathrm{Pb}$ in corn starch, thus, contributing to increased contamination of the final product(s).

The concentration of elemental impurities in herbal medicines and excipients must be controlled and, when present, documented. The acceptable levels for impurities depend on the end use of the material. Therefore, the manufacturers of herbal medicines must determine the acceptable levels of elemental impurities in the herbal raw material, excipients and/or adjuvant substances used to produce their products.

The World Health Organization (WHO, 2007) and the US Food and Drug Administration have set limits for the occurrence of certain elements such as the heavy metals $\mathrm{As}, \mathrm{Hg}, \mathrm{Pb}$ and $\mathrm{Cd}$ in herbal materials. However, the WHO has not yet decided what limits are allowed on medicinal plants for all metals, because many of these metals are also essential micronutrients for the diet of living beings (SARMA et al., 2011).

Many countries, including Brazil, do not have established regulatory limits for heavy metals in plant products and preparations therefrom.

In Brazil, there is the Resolution RDC n. 42 (ANVISA, 2013) of the Collegiate Board of the Sanitary Surveillance Agency (ANVISA) that brings maximum limits of inorganic contaminants in food. The United States Pharmacopeia (USP, 2006) only establishes a maximum limit for the sum of heavy metals, such as lead, while other pharmacopeias, such as the Canadian, stipulates limits for As, $\mathrm{Pb}, \mathrm{Cd}$ and $\mathrm{Hg}$. 
Table 2 - Chemical elements identified and quantified (mean concentrations and associated standard deviations expressed in $\mu \mathrm{gg}^{-1}$ ) in samples 1 to 7 of the dried extracts of medicinal plants.

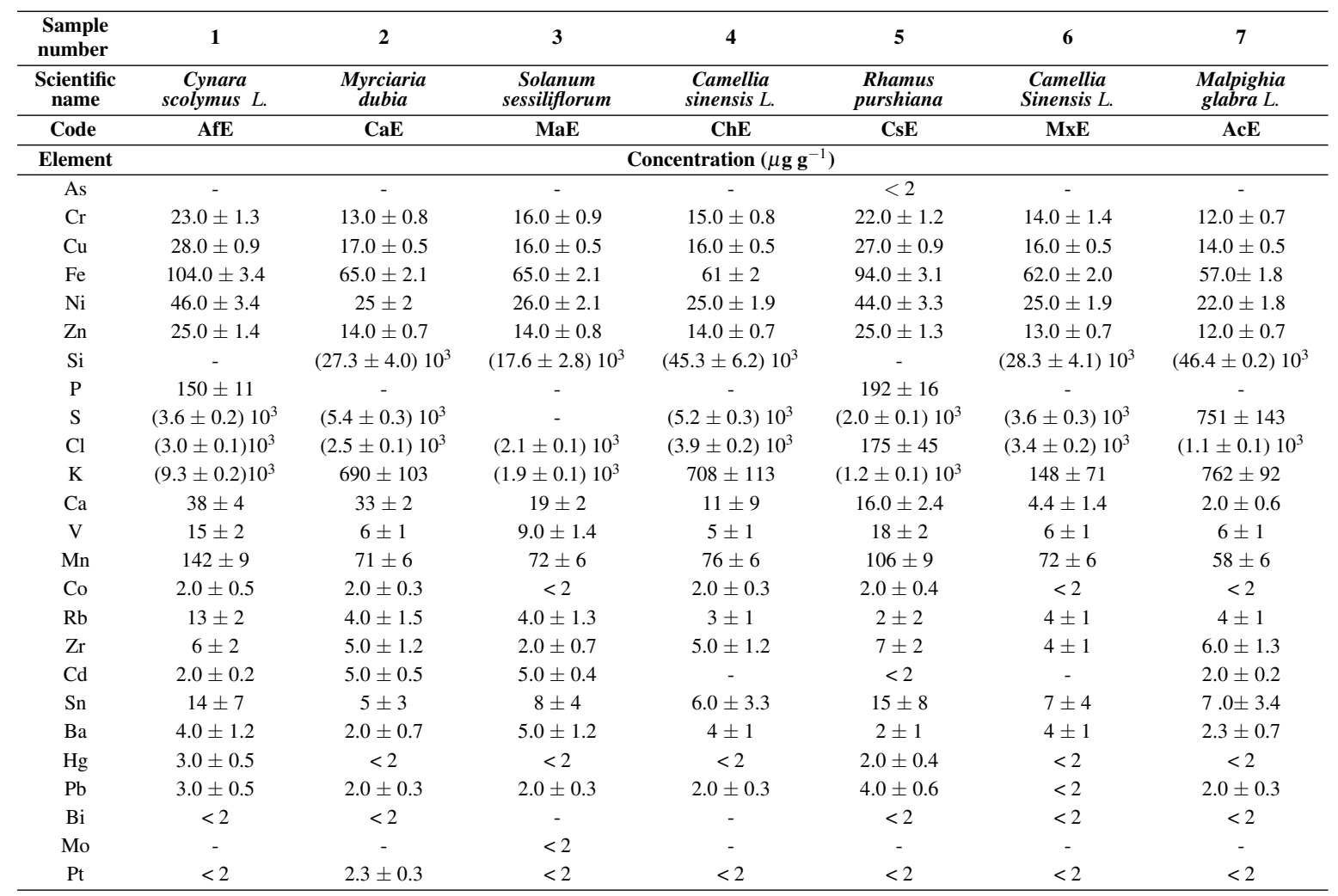

Source: The authors.

Table 3 - Chemical elements identified and quantified (mean concentrations and associated standard deviations expressed in $\mu \mathrm{g} \mathrm{g}^{-1}$ ) in samples 8 to 14 of the dried extracts of medicinal plants (cont.).

\begin{tabular}{|c|c|c|c|c|c|c|c|}
\hline $\begin{array}{l}\text { Sample } \\
\text { number }\end{array}$ & 8 & 9 & 10 & 11 & 12 & 13 & 14 \\
\hline $\begin{array}{l}\text { Scientific } \\
\text { name }\end{array}$ & $\begin{array}{l}\text { Paullinia } \\
\text { cupana K. }\end{array}$ & $\begin{array}{c}\text { Illex } \\
\text { paraguariensis }\end{array}$ & $\begin{array}{c}\text { Maytenus } \\
\text { sessiliflorum }\end{array}$ & $\begin{array}{c}\text { Echinacea } \\
\text { purpurea } L .\end{array}$ & $\begin{array}{c}\text { Melissa } \\
\text { officinalis } L .\end{array}$ & $\begin{array}{c}\text { Passiflora } \\
\text { incarnata } L .\end{array}$ & $\begin{array}{c}\text { Aesculus } \\
\text { hippocastanum L. }\end{array}$ \\
\hline Code & GuE & MtE & EsE & EqE & MeE & PaE & CtE \\
\hline Element & \multicolumn{7}{|c|}{ Concentration $\left(\mu \mathbf{g ~ g}^{-1}\right)$} \\
\hline As & - & - & $<2$ & $<2$ & $2.0 \pm 0.2$ & - & - \\
\hline $\mathrm{Cr}$ & $19.6 \pm 1.1$ & $16 \pm 1$ & $18 \pm 1$ & $24.0 \pm 1.5$ & $23.0 \pm 1.4$ & $25.0 \pm 1.5$ & $12.0 \pm 0.7$ \\
\hline $\mathrm{Cu}$ & $22.0 \pm 0.7$ & $20.6 \pm 0.7$ & $21.0 \pm 0.7$ & $35 \pm 1$ & $36 \pm 1$ & $35 \pm 1$ & $20.0 \pm 0.6$ \\
\hline $\mathrm{Fe}$ & $90 \pm 3$ & $94 \pm 3$ & $78.0 \pm 2.5$ & $120 \pm 4$ & $108 \pm 4$ & $127 \pm 4$ & $60 \pm 2$ \\
\hline $\mathrm{Ni}$ & $39 \pm 3$ & $32 \pm 3$ & $33.3 \pm 2.4$ & $51 \pm 4$ & $49 \pm 4$ & $51 \pm 4$ & $25 \pm 2$ \\
\hline $\mathrm{Zn}$ & $21.0 \pm 1.2$ & $19.9 \pm 0.9$ & $18.3 \pm 1.0$ & $33.2 \pm 1.5$ & $29.4 \pm 1.4$ & $30.6 \pm 1.4$ & $14.5 \pm 0.7$ \\
\hline $\mathrm{Si}$ & - & $(35.1 \pm 5.1) 10^{3}$ & $(20.3 \pm 3.3) 10^{3}$ & - & - & - & $(214.7 \pm 26.9) 10^{3}$ \\
\hline $\mathrm{P}$ & $42 \pm 38$ & $(1.3 \pm 0.2) 10^{3}$ & $989 \pm 464$ & $222 \pm 170$ & $873 \pm 359$ & $204 \pm 224$ & $(5.9 \pm 1.4) 10^{3}$ \\
\hline S & $(2.3 \pm 0.1) 10^{3}$ & $(4.3 \pm 0.3) 10^{3}$ & $(6.8 \pm 0.3) 10^{3}$ & $153 \pm 29$ & $499 \pm 50$ & $(2.0 \pm 0.1) 10^{3}$ & $(1.2 \pm 0.2) 10^{3}$ \\
\hline $\mathrm{Cl}$ & $(1.9 \pm 0.1) 10^{3}$ & $(2.6 \pm 0.1) 10^{3}$ & $(4.9 \pm 0.2) 10^{3}$ & $(1.00 \pm 0.04) 10^{3}$ & $(1.73 \pm 0.06) 10^{3}$ & $(4.7 \pm 0.1) 10^{3}$ & $989 \pm 52$ \\
\hline $\mathrm{K}$ & $490 \pm 117$ & $(12.5 \pm 0.3) 10^{3}$ & $(8.9 \pm 0.2) 10^{3}$ & $(19.5 \pm 0.4) 10^{3}$ & $(33.9 \pm 0.6) 10^{3}$ & $(25.1 \pm 0.5) 10^{3}$ & $(31.2 \pm 0.6) 10^{3}$ \\
\hline $\mathrm{Ca}$ & $101 \pm 11$ & $228 \pm 19$ & $532 \pm 25$ & $289 \pm 13$ & $51 \pm 16$ & $(1.07 \pm 0.04) 10^{3}$ & $88 \pm 18$ \\
\hline $\mathrm{V}$ & $8.0 \pm 1.4$ & $7.0 \pm 1.2$ & $12 \pm 2$ & $10 \pm 2$ & $17.0 \pm 2.5$ & $13 \pm 2$ & $6 \pm 1$ \\
\hline $\mathrm{Mn}$ & $102 \pm 8$ & $385 \pm 11$ & $94 \pm 7$ & $187 \pm 10$ & $127 \pm 11$ & $137 \pm 10$ & $59 \pm 8$ \\
\hline Co & $2.0 \pm 0.4$ & $<2$ & $2.0 \pm 0.3$ & $4.0 \pm 0.6$ & $3.0 \pm 0.5$ & $2.4 \pm 0.5$ & $<2$ \\
\hline $\mathrm{Rb}$ & $5.0 \pm 1.7$ & $9.0 \pm 1.1$ & $10.0 \pm 1.1$ & $21.0 \pm 1.5$ & $26.0 \pm 1.5$ & $14.0 \pm 1.7$ & $7.0 \pm 0.9$ \\
\hline $\mathrm{Zr}$ & $8.8 \pm 2.1$ & $7.1 \pm 1.7$ & $10.0 \pm 2.2$ & $8.0 \pm 2.1$ & $6.5 \pm 1.9$ & $16.0 \pm 3.5$ & $3.1 \pm 0.9$ \\
\hline $\mathrm{Cd}$ & $<2$ & $2.0 \pm 0.3$ & $4.0 \pm 0.4$ & $2.0 \pm 0.4$ & $2.0 \pm 0.3$ & $3.0 \pm 0.4$ & $<2$ \\
\hline $\mathrm{Sn}$ & $10.1 \pm 5.3$ & $13.8 \pm 6.5$ & $11.1 \pm 5.5$ & $14.6 \pm 7.7$ & $20.3 \pm 9.9$ & $11.8 \pm 6.4$ & $6.9 \pm 3.6$ \\
\hline $\mathrm{Ba}$ & $<2$ & $<2$ & $2.9 \pm 1.0$ & - & - & - & $<2$ \\
\hline $\mathrm{Hg}$ & $<2$ & $<2$ & $2.5 \pm 0.4$ & $5.3 \pm 0.7$ & $18.0 \pm 1.2$ & $4.4 \pm 0.7$ & $<2$ \\
\hline $\mathrm{Pb}$ & $3.1 \pm 0.5$ & $2.0 \pm 0.3$ & $2.0 \pm 0.3$ & $3.6 \pm 0.5$ & $2.5 \pm 0.5$ & $4.2 \pm 0.6$ & $<2$ \\
\hline $\mathrm{Bi}$ & $<2$ & $<2$ & $<2$ & $<2$ & $<2$ & $<2$ & $<2$ \\
\hline Mo & - & - & - & - & - & - & - \\
\hline $\mathrm{Pt}$ & $<2$ & $<2$ & $<2$ & $<2$ & $<2$ & $2.2 \pm 0.5$ & $<2$ \\
\hline
\end{tabular}

Source: The authors. 
Table 4 - Chemical elements identified and quantified (mean concentrations and associated standard deviations expressed in $\mu \mathrm{g} \mathrm{g}^{-1}$ ) in samples 15 to 20 of the grinded medicinal plants.

\begin{tabular}{|c|c|c|c|c|c|c|}
\hline $\begin{array}{c}\text { Sample } \\
\text { number }\end{array}$ & 15 & 16 & 17 & 18 & 19 & 20 \\
\hline $\begin{array}{c}\text { Scientific } \\
\text { name }\end{array}$ & $\begin{array}{c}\text { Echinacea } \\
\text { purpurea } L .\end{array}$ & $\begin{array}{l}\text { Maytenus } \\
\text { ilicifolia L. }\end{array}$ & $\begin{array}{c}\text { Camellia } \\
\text { sinensis L. }\end{array}$ & $\begin{array}{c}\text { Rhamus } \\
\text { purshiana }\end{array}$ & $\begin{array}{c}\text { Cynara } \\
\text { scolymus } L\end{array}$ & $\begin{array}{c}\text { Paulina } \\
\text { cupana K. }\end{array}$ \\
\hline Code & EqM & EsM & ChM & CsM & AfM & GuM \\
\hline Element & \multicolumn{6}{|c|}{ Concentration $\left(\mu \mathrm{g} \mathrm{g}^{-1}\right)$} \\
\hline As & - & - & - & $<2$ & - & - \\
\hline $\mathrm{Cr}$ & $14.0 \pm 1.1$ & $21.6 \pm 1.4$ & $21.2 \pm 1.3$ & $23.9 \pm 1.6$ & $12.1 \pm 1.0$ & $24.2 \pm 1.4$ \\
\hline $\mathrm{Cu}$ & $32.7 \pm 1.1$ & $34.7 \pm 1.1$ & $41.7 \pm 1.3$ & $37.2 \pm 1.2$ & $31.7 \pm 1.0$ & $40.9 \pm 1.3$ \\
\hline $\mathrm{Fe}$ & $412 \pm 8$ & $180 \pm 5$ & $339 \pm 7$ & $215 \pm 6$ & $505 \pm 9$ & $228 \pm 5$ \\
\hline $\mathrm{Ni}$ & $47.0 \pm 4.2$ & $51.5 \pm 3.9$ & $53.6 \pm 4.2$ & $56.8 \pm 4.5$ & $45.8 \pm 4.5$ & $49.9 \pm 3.6$ \\
\hline $\mathrm{Zn}$ & $30.8 \pm 1.5$ & $33.1 \pm 1.5$ & $40.0 \pm 1.6$ & $34.1 \pm 1.7$ & $32.1 \pm 1.5$ & $34.3 \pm 1.5$ \\
\hline $\mathrm{Si}$ & $(6.1 \pm 1.5) 10^{3}$ & - & - & - & $(3.6 \pm 1.1) 10^{3}$ & - \\
\hline$P$ & $(3.4 \pm 0.4) 10^{3}$ & $(2.0 \pm 0.3) 10^{3}$ & $(2.1 \pm 0.3) 10^{3}$ & $576 \pm 331$ & $(1.8 \pm 0.3) 10^{3}$ & $(1.9 \pm 0.3) 10^{3}$ \\
\hline S & $(1.4 \pm 0.1) 10^{3}$ & $(1.10 \pm 0.08) 10^{3}$ & $(1.7 \pm 0.1) 10^{3}$ & $288 \pm 39$ & $(2.3 \pm 0.1) 10^{3}$ & $(1.1 \pm 0.1) 10^{3}$ \\
\hline $\mathrm{Cl}$ & $155 \pm 10$ & $(4.5 \pm 0.1) 10^{3}$ & $472 \pm 25$ & - & $(12.0 \pm 0.3) 10^{3}$ & $449 \pm 25$ \\
\hline $\mathrm{K}$ & $(30.1 \pm 0.5) 10^{3}$ & $(18.6 \pm 0.4) 10^{3}$ & $(18.9 \pm 0.4) 10^{3}$ & $(4.2 \pm 0.1) 10^{3}$ & $(50.3 \pm 0.9) 10^{3}$ & $(12.3 \pm 0.3) 10^{3}$ \\
\hline $\mathrm{Ca}$ & $(21.5 \pm 0.6) 10^{3}$ & $(12.8 \pm 0.3) 10^{3}$ & $(8.5 \pm 0.2) 10^{3}$ & $(18.7 \pm 0.5) 10^{3}$ & $(25.4 \pm 0.7) 10^{3}$ & $170 \pm 7$ \\
\hline $\mathrm{Ti}$ & $214 \pm 22$ & - & $112 \pm 30$ & $189 \pm 51$ & $231 \pm 19$ & $72 \pm 23$ \\
\hline $\mathrm{V}$ & $5.5 \pm 1.4$ & $4.2 \pm 1.1$ & $5.8 \pm 1.3$ & $4.5 \pm 3.3$ & $6.0 \pm 1.6$ & $9.9 \pm 1.8$ \\
\hline $\mathrm{Mn}$ & $214 \pm 10$ & $170 \pm 10$ & $(1.85 \pm 0.04) 10^{3}$ & $413 \pm 14$ & $165 \pm 10$ & $143 \pm 10$ \\
\hline Co & $3.5 \pm 1.1$ & $2.5 \pm 0.6$ & $2.5 \pm 1.0$ & $1.9 \pm 0.7$ & $3.7 \pm 1.2$ & $3.7 \pm 0.8$ \\
\hline $\mathrm{Rb}$ & $19.0 \pm 1.5$ & $14.7 \pm 1.9$ & $41.8 \pm 1.7$ & $19.6 \pm 1.9$ & $37.7 \pm 1.6$ & $16.1 \pm 1.6$ \\
\hline $\mathrm{Zr}$ & $28.8 \pm 4.0$ & $21.6 \pm 4.4$ & $22.1 \pm 4.7$ & $39.0 \pm 3.5$ & $31.1 \pm 3.4$ & $18.7 \pm 3.9$ \\
\hline $\mathrm{Cd}$ & $1.8 \pm 0.2$ & $1.9 \pm 0.2$ & $0.5 \pm 0.1$ & $2.0 \pm 0.3$ & $1.1 \pm 0.2$ & $1.8 \pm 0.2$ \\
\hline Sn & $17.3 \pm 8.7$ & $16.7 \pm 8.5$ & $20.8 \pm 10.2$ & $23.2 \pm 11.5$ & $13.5 \pm 7.1$ & $14.1 \pm 7.4$ \\
\hline $\mathrm{Ba}$ & - & - & - & $35.9 \pm 4.4$ & - & $3.6 \pm 1.3$ \\
\hline $\mathrm{Hg}$ & $6.4 \pm 0.8$ & $2.8 \pm 0.6$ & $<2$ & $<2$ & $8.2 \pm 0.8$ & $2.9 \pm 0.6$ \\
\hline $\mathrm{Pb}$ & $2.7 \pm 0.4$ & $3.1 \pm 0.5$ & $4.0 \pm 0.6$ & $3.9 \pm 0.6$ & $3.3 \pm 0.5$ & $4.0 \pm 0.6$ \\
\hline $\mathrm{Bi}$ & $<2$ & $2.0 \pm 0.5$ & $<2$ & $<2$ & $<2$ & $<2$ \\
\hline Mo & - & - & - & - & $<2$ & - \\
\hline $\mathrm{Pt}$ & - & $<2$ & - & - & - & $3.1 \pm 0.6$ \\
\hline
\end{tabular}

Source: The authors.

Table 5 - Chemical elements identified and quantified (mean concentrations and associated standard deviations expressed in $\mu \mathrm{g} \mathrm{g}^{-1}$ ) in the adjuvants and/or excipients.

\begin{tabular}{|c|c|c|c|c|}
\hline Adjuvants & Corn starch & Maltodextrin & Silicon dioxide & Dye caramel \\
\hline Element & \multicolumn{4}{|c|}{ Concentration $\left(\mu \mathbf{g ~ g}^{-1}\right)$} \\
\hline As & - & $<2$ & - & $<2$ \\
\hline $\mathrm{Cr}$ & $22.1 \pm 1.2$ & $22.7 \pm 1.2$ & $11.0 \pm 0.6$ & $13.8 \pm 1.1$ \\
\hline $\mathrm{Cu}$ & $40.0 \pm 1.4$ & $36.6 \pm 1.3$ & $11.8 \pm 0.4$ & $27.4 \pm 1.0$ \\
\hline $\mathrm{Fe}$ & $109.1 \pm 3.7$ & $105.0 \pm 3.5$ & $46.4 \pm 1.5$ & $92.5 \pm 3.5$ \\
\hline $\mathrm{Ni}$ & $68.5 \pm 5.0$ & $65.3 \pm 4.7$ & $18.2 \pm 2.2$ & $64.9 \pm 4.7$ \\
\hline $\mathrm{Zn}$ & $40.2 \pm 2.3$ & $35.6 \pm 2.2$ & $12.1 \pm 0.6$ & $33.9 \pm 2.2$ \\
\hline $\mathrm{Si}$ & - & - & $(856 \pm 105) 103$ & - \\
\hline$P$ & - & - & - & - \\
\hline S & - & - & - & - \\
\hline $\mathrm{Cl}$ & - & $141 \pm 10$ & $66 \pm 41$ & - \\
\hline K & $424 \pm 69$ & $424 \pm 75$ & $363 \pm 38$ & $716 \pm 57$ \\
\hline $\mathrm{Ca}$ & - & - & - & - \\
\hline $\mathrm{Ti}$ & - & - & $84.5 \pm 22.1$ & $44.5 \pm 15.5$ \\
\hline $\mathrm{V}$ & $16.5 \pm 2.1$ & $17.1 \pm 2.1$ & $14.5 \pm 1.6$ & $3.4 \pm 0.9$ \\
\hline $\mathrm{Mn}$ & $112 \pm 10$ & $111.2 \pm 9.5$ & $3.1 \pm 10.1$ & $99.4 \pm 18.5$ \\
\hline Co & $2.1 \pm 0.6$ & $2.2 \pm 0.6$ & $<2$ & $2.0 \pm 0.6$ \\
\hline $\mathrm{Rb}$ & $23.0 \pm 5.0$ & $6.2 \pm 3.0$ & $4.2 \pm 1.1$ & $4.9 \pm 3.4$ \\
\hline $\mathrm{Zr}$ & $25.5 \pm 6.2$ & $8.2 \pm 2.7$ & $11.0 \pm 1.8$ & $11.6 \pm 3.3$ \\
\hline $\mathrm{Cd}$ & $2.0 \pm 0.2$ & $18.2 \pm 2.4$ & $<2$ & $66.2 \pm 5.1$ \\
\hline $\mathrm{Sn}$ & $52.5 \pm 25.5$ & $28.8 \pm 15.1$ & $6.3 \pm 3.1$ & $36.2 \pm 18.1$ \\
\hline $\mathrm{Ba}$ & $6.3 \pm 1.6$ & $2.0 \pm 0.9$ & $14.2 \pm 1.5$ & $<2$ \\
\hline $\mathrm{Hg}$ & $2.1 \pm 0.7$ & $2.5 \pm 0.8$ & $<2$ & $3.6 \pm 0.8$ \\
\hline $\mathrm{Pb}$ & $14.0 \pm 1.5$ & $3.5 \pm 0.5$ & $<2$ & $2.0 \pm 0.5$ \\
\hline $\mathrm{Bi}$ & $5.2 \pm 1.1$ & $<2$ & $<2$ & $2.0 \pm 0.5$ \\
\hline Mo & - & - & - & - \\
\hline $\mathrm{Pt}$ & $2.0 \pm 0.7$ & $2.3 \pm 0.7$ & - & - \\
\hline
\end{tabular}

Source: The authors. 
Heavy metals

According to Herrera-Estrella and Guevara-Garcia (2009), any metal or metalloid that causes environmental problems should be a "heavy metal". Heavy metals are distributed in nature and appear on soil, water and air. Plants absorb and concentrate these elements which eventually end up in living beings after consuming them either naturally or as part of preparations in the form of teas, extracts or medicines. The heavy metals that present greater toxicity to living beings have been proven to produce cancer, when ingested above certain limits.

Comparing the levels of the heavy metals $\mathrm{As}, \mathrm{Pb}$, $\mathrm{Hg}$, and $\mathrm{Cd}$ in the extracts of plants and in the ground medicinal plants analyzed in this study, one verified that the As appear in the extracts of M. officinalis L. with 2.0 $\pm 0.2 \mu \mathrm{g} \mathrm{g}^{-1}$ and E. purpurea L. with a trace concentration $<2 \mu \mathrm{g} \mathrm{g}^{-1}$ respectively, below the predicted limits by most regulatory agencies, except by ANVISA (ANVISA, 2013). The adjuvant maltodextrin presented levels of As concentration $<0.2 \mu \mathrm{g} \mathrm{g}^{-1}$. Even at low levels, exposure to As can cause nausea, vomiting, reduced production of erythrocytes and leukocytes, abnormal heart beating and damage to blood vessels (JAISHANKAR et al., 2014). Long-term exposure to As may lead to the formation of internal skin lesions, cancers, neurological problems, pulmonary disease, peripheral vascular disease, hypertension, and cardiovascular diseases and Diabetes mellitus (SMITH; LINGAS; RAHMAN, 2000).

The presence of $\mathrm{Pb}$ was detected in all extracts and ground medicinal plants. $\mathrm{Pb}$ ingested beyond a certain threshold may increase blood pressure accompanied by debilitating effects on key organs such as kidneys and brain (NKANSAH et al., 2016). Acute exposure to $\mathrm{Pb}$ can cause loss of appetite, headache, hypertension, abdominal pain, renal dysfunction, fatigue, insomnia, arthritis, hallucinations and vertigo (JAISHANKAR et al., 2014). The average concentration of $\mathrm{Pb}$ found in the extracts of medicinal plants was $2.47 \mu \mathrm{g} \mathrm{g}^{-1}$ whereas that found in ground plants was $3.50 \mu \mathrm{g} \mathrm{g}^{-1}$, it was below the acceptable limits for this metal, by most regulatory agencies, except by ANVISA (ANVISA, 2013).

The production process of the extracts seems to have low efficiency for the extraction of the main chemical elements present in the ground plants, as can be observed when comparing the data presented in Tables 2 and 3 with the data presented in Table 4. For the majority of the elements, the concentration of the chemical elements decreases in the extracts when com- pared to the same elements present in the ground plants, being undesirable when we are interested in the extraction of elements essential for the good functioning of living organisms, such as $\mathrm{Ca}, \mathrm{Fe}, \mathrm{K}$, among others. However, the low efficiency in the extraction can be a good thing, when the extraction process involves heavy metals such as $\mathrm{Pb}$, since one always looks for the lowest possible levels of these elements in the final product(s).

Cadmium poisoning is associated with several disorders, such as renal failure and cardiovascular problems (NKANSAH et al., 2016). Cd ingestion may cause bone mineralization through bone damage or renal dysfunction (JAISHANKAR et al., 2014). Exposure to low concentrations of Cd for long periods of time promotes its deposition in the kidneys leading to kidney disease, fragile bones and damage to the lungs (BERNARD, 2008). The limit recommended by the different regulatory agencies for the intake of $\mathrm{Cd}$ is low, less than $1 \mu \mathrm{g} \mathrm{g}^{-1}$. Considering all medicinal plant extracts, ground medicinal plants and adjuvants used, the mean levels found for $\mathrm{Cd}$ were $2.14 \mu \mathrm{g} \mathrm{g}^{-1},<2 \mu \mathrm{g} \mathrm{g}^{-1}$ and $21.75 \mu \mathrm{g} \mathrm{g}^{-1}$, respectively, indicating a high contamination by this element in plant extracts and adjuvants, however, with special emphasis on the high concentration of $\mathrm{Cd}$ found in adjuvants.

In the present study, it was not possible to obtain details about the use of the adjuvants listed in Table 5, from the manufacturers of the extracts of medicinal plants. Thus, it is not possible to affirm that a certain extract has high levels of contamination of a certain element, due to the use of some adjuvants. However, it was observed that two adjuvants widely used by the food and pharmaceutical industries in their production processes exhibited levels of $\mathrm{Cd}$ much higher than those recommended by the regulatory agencies, namely in maltodextrin which presented $18.2 \pm 0.2 \mu \mathrm{g} \mathrm{g}^{-1}$ of $\mathrm{Cd}$ and in dye caramel which presented $66.2 \pm 5.1 \mu \mathrm{g} \mathrm{g}^{-1}$ of $\mathrm{Cd}$, indicating that if these adjuvants were used they contributed to the increase in the final levels of $\mathrm{Cd}$ contaminant in the extracts of the medicinal plants.

Exposure to the organic and/or inorganic $\mathrm{Hg}$ element can damage the developing brain, kidneys, and fetus (ALINA et al., 2012). Exposure to high doses of $\mathrm{Hg}$ can alter brain functions and lead to tremors, memory problems, irritability, and changes in vision and hearing (JAISHANKAR et al., 2014). The acceptable limits for exposure to $\mathrm{Hg}$ element provided by the different regulatory agencies are very low, less than $0.5 \mu \mathrm{g} \mathrm{g}^{-1}$, indicating the high degree of toxicity of this metal to living beings. 
All extracts and ground plants showed levels of $\mathrm{Hg}$ above the limits recommended by the regulatory agencies and/or pharmacopeias, however, the levels of $\mathrm{Hg}$ found for the $M$. officinalis L. extract of $18.0 \pm 1.2 \mu \mathrm{g} \mathrm{g}^{-1}$ are worrisome.

The maximum amounts of metals in medicinal plants can also be provided based on the Provisional Tolerable Intake values (PTI), established by the World Health Organization WHO and the Food and Agriculture Organization (FAO). Another quantity has also been proposed, called Provisional Tolerable Weekly Intake (PTWI), which measures the acceptable levels of toxic substances that can be ingested weekly, generally used when contaminants can accumulate in the body. The PTWI proposed for some heavy metals are $\mathrm{Hg}\left(5 \mu \mathrm{g} \mathrm{g}^{-1} \mathrm{~kg}^{-1}\right.$ b.w.) (b.w. means body weigh), As (15 $\mu \mathrm{g} \mathrm{g}^{-1} \mathrm{~kg}^{-1}$ b.w.), $\mathrm{Pb}\left(25 \mu \mathrm{g} \mathrm{g}^{-1}\right.$ $\mathrm{kg}^{-1}$ b.w.) and $\mathrm{Cd}\left(7 \mu \mathrm{g} \mathrm{g}^{-1} \mathrm{~kg}^{-1}\right.$ b.w.) (FAO; WHO, 2005; WHO, 1978, 1989, 2000).

\section{Other metal and non-metallic elements}

For the great majority of chemical elements present in plant products, there are no predictions in the different pharmacopoeias for the maximum intake doses, because about 50 elements are vital for human health (TOLONEN, 1990). However, for pharmaceutical products these values are well established in the different pharmacopeias through the Permitted Daily Exposure (PDE) (ICH, 2014).

Chemical elements classified as minerals are those that appear in the diet at PDE higher than $100 \mathrm{mg} / \mathrm{day}$, and socalled trace elements are those that should enter the diet but at PDE less than $100 \mathrm{mg} /$ day (SARMA et al., 2011). The mineral elements include $\mathrm{Ca}, \mathrm{Mg}, \mathrm{P}, \mathrm{Na}, \mathrm{K}, \mathrm{S}$ and $\mathrm{Cl}$, and the trace elements necessary for the human health are $\mathrm{Fe}, \mathrm{Cu}, \mathrm{Mn}, \mathrm{Zn}$, Se, Cr, among others (HENDLER, 1991). For chemical elements that do not have cumulative properties in the human body, the Provisional Maximum Tolerable Daily Intake (PMTDI) is the quantity usually used to quantify them. In these cases, a range of values representing the recommended minimum and maximum PMTDI dose is used. For example, the range for: $\mathrm{Cu}\left(0.05-0.5 \mathrm{mg} \mathrm{Kg}^{-1}\right.$ b.w.), Zn (0.3 - $1 \mathrm{mg} \mathrm{Kg}^{-1}$ b.w.) and $\mathrm{Sn}\left(0-2 \mathrm{mg} \mathrm{Kg}^{-1}\right.$ b.w.) (WHO, 1982).

\section{Multivariate Data Analysis: Clustering and PCA}

\section{Clustering}

When analyzing large amounts of data to find patterns and/or outliers, Clustering Analysis or Principal Component Analysis (PCA) can be a useful tool. In this work, the multivariate analysis of the data was done on the basis of a table, where the data was organized in such a way that the rows in the table represent the objects (medicinal extracts, medicinal ground plants and adjuvants) and the columns are the attributes, being represented by the chemical elements measured by EDXRF. From the first row up to row 14 one placed the extracts, from row 15 to row 20 the ground plants were included and from row 21 to row 24 the adjuvants were added. The purpose of the cluster analysis was to verify the occurrence of two types of correlations:

i) between the attributes;

ii) between the objects studied.

Figure 5 displays the results of clustering analysis in the form of a dendrogram, where it is possible to identify some correlations between the attributes (chemical elements). The purpose of this analysis was to infer, through these correlations, whether the occurrence of certain chemical elements, especially heavy metals, is important to characterize the soil where the crop was or possible contaminations in the productive process. On the left side of the dendrogram exhibited in Figure 5, groups of highly correlated elements $(>0.9)$ are observed. Analyzing the heavy metals, it is observed that $\mathrm{Cd}$ and $\mathrm{Pb}$ are in different groups than that formed by the elements $\mathrm{Hg}$ and As. Considering correlations above 0.8 , it is noted that the elements are grouped in well-defined sets, that is, the group formed by $\mathrm{Ti}$ and $\mathrm{Cd}$, the group formed by $\mathrm{Co}, \mathrm{Hg}, \mathrm{Pt}, \mathrm{Mo}, \mathrm{Pd}$, As, $\mathrm{Ba}$ and $\mathrm{Bi}$, plus the sub groups formed by $\mathrm{Rb}, \mathrm{Zr}, \mathrm{Pb}, \mathrm{Cr}$ and $\mathrm{V}$, and $\mathrm{Fe}, \mathrm{Mn}, \mathrm{Ni}, \mathrm{Cu}, \mathrm{Zn}$ and $\mathrm{Sn}$.

Figure 5 - Dendrogram showing correlations between the chemical elements found in the samples analyzed (medicinal plant extracts, medicinal ground plants and adjuvants).

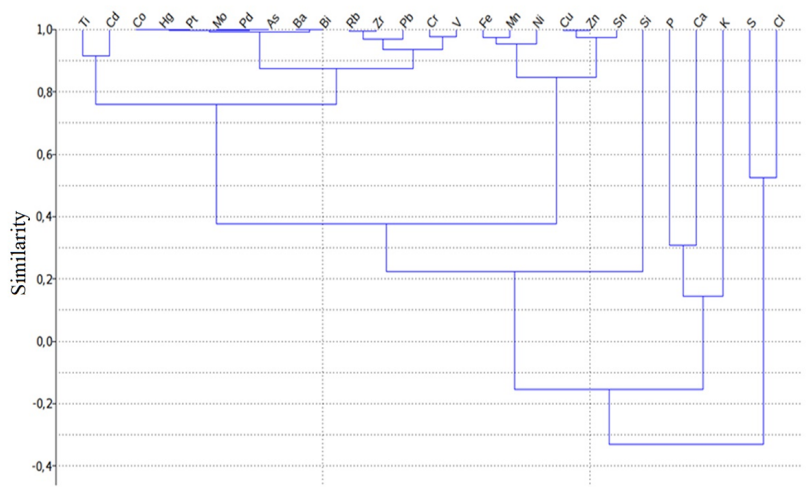

Source: The authors. 
Considering a slightly lower cut-off correlation (0.75), the inclusion of all heavy metals in the leftmost branch is observed, especially those that demand more attention on contamination $(\mathrm{Cd}, \mathrm{Hg}, \mathrm{As}$ and $\mathrm{Pb})$. The other elements appearing in the dendrogram, viz. Si, $\mathrm{P}, \mathrm{Ca}, \mathrm{K}, \mathrm{S}$ and $\mathrm{Cl}$, do not correlate significantly with each other, nor between any other elements, probably due to both their importance in metabolic processes and in the constitution of each plant and soil.

To verify the existence of correlations between the objects analyzed in this study (viz. medicinal plant extracts, medicinal ground plants and adjuvants), one used the dendrogram (emphasized by a colormap) displayed as Figure 6.

Figure 6 - Color scale matrix of correlations between medicinal plants. At the edges, one can find dendrograms representing the clusters formed by similarity.

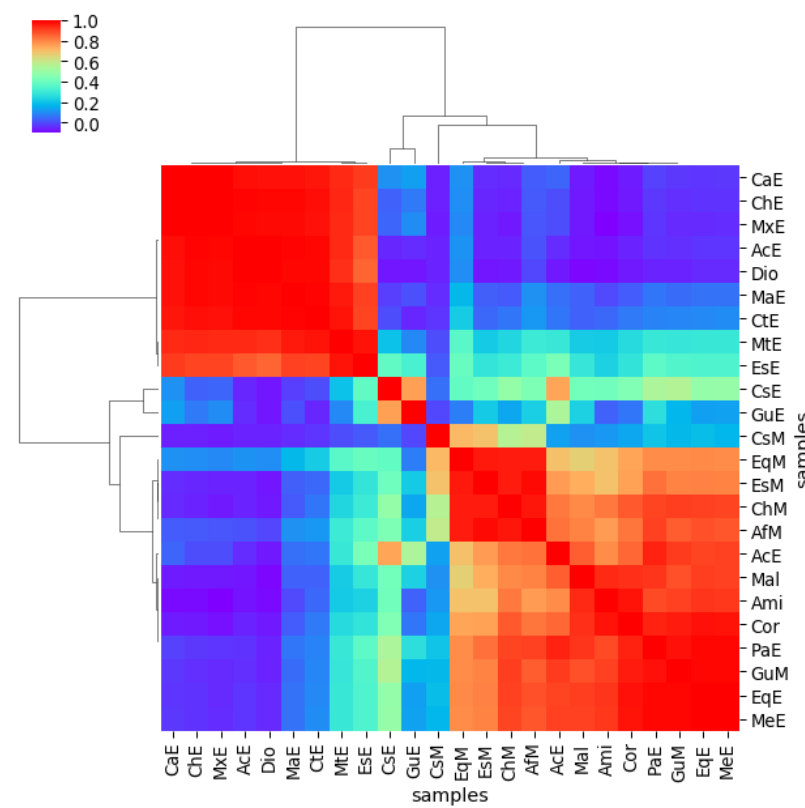

Source: The authors.

Legend: AcE- M. glabra L. dried extract; AfE- C. scolymus L. dried extract; AfM- C. scolymus L. ground plant; Ami- Corn starch; CaE- M. dubia dried extract; ChE- $C$. sinensis L. dried extract; ChM- $C$. sinensis L. ground plant; Cor- Dye caramel (adjuvant); CsE- R. purshiana dried extract; CsM- R. purshiana ground plant; CtE- A. hippocastanum L. dried extract; Dio- Silicon dioxide; EqE- E. purpurea L. dried extract; EqM- E. purpurea L. ground plant; EsE- M. ilicifolia L. ground plant; EsM: M. ilicifolia L. ground plant; GuE- P. cupana K. dried extract; GuM- $P$. cupana K. ground plant; MaE- S. sessiliflorum dried extract; Mal- Maltodextrin; MeE- M. officinalis L. dried extract; MtE- I. paraguariensis dried extract; MxE- Matchá $C$. sinensis L. dried extract; PaE- P. incarnata L. dried extract.

An analysis of the sequence of the samples grouped in Figure 6 leads to observation that, from the extract of M. dubia (CaE) to the extract of M. ilicifolia L. (EsE) the experimental data is highly correlated (correlation around unity). This group includes only the dried extracts and the adjuvant silicon dioxide (Dio). The Dio was included in the analysis performed because this adjuvant was used in the production process of almost all the samples of dried extracts, while being absent or appearing in low concentrations in the ground medicinal plants.

The extracts of $P$. cupana K. (GuE) and $R$. purshiana (CsE) make up a distinct group. Another large group observed in the dendrogram displayed in Figure 6 is formed by the ground plants and adjuvants used in the manufacture process. In this group, the extracts of C. scolymus L. (MaE), P. incarnata L. (PaE), E. purpurea L. (EqE) and M. officinalis L. (MeE) also appear. An in-depth analysis of the dendrogram in this region, leads to observation that there is a strongly correlated subgroup formed by the ground plants of E. purpurea $\mathrm{L}$. (EqM), M. ilicifolia L. (EsM), C. sinensis L. (ChM) and C. scolymus L. (AfM).

The adjuvants corn starch and maltodextrin do not contribute to discriminate the mode of preparation of the dried extracts (see Figure 6). On the other hand, it was expected that the ground plants showed a strong correlation with their respective dried extracts; however, this correlation was only observed for the $C$. scolymus L. and E. purpurea L. plants, indicating once again that the production process used in the preparation of the extracts has a low efficiency in the extraction of the main chemical elements present in the ground plants, verified by the low correlation between them.

\section{$P C A$}

In order to do a Principal Component Analysis (PCA), the first step is to check how many principal components should be used to correctly describe the problem under study. In the study performed and described herein, it was verified that only two components would suffice to describe the behavior of the data. In Figure 7 one can observe how the plants are distributed in relation to the first two principal components (loadings), whereas in Figures 8 and 9 one can observe how the chemical elements are distributed in relation to the same components (scores).

From inspection of Figure 7 one can see that the distribution of the ground plants and extracts is grouped in a way coherent with that observed in Figure 6, that is, the extracts from $\mathrm{CaE}$ up to the EsE are highly correlated with a high loading in the PC2, associated with the adjuvant silicon dioxide (the $\mathrm{Si}$ element presents a very high in this same component, as shown in Figure 8). The other group of plants presents high loadings in the $\mathrm{PC} 1$ component as shown in Figure 7, strongly associated with the presence of $\mathrm{K}$ (presenting a very high score in this component, as can be seen in Figure 8). 
Figure 7 - Loadings in the first two principal components.

Source: The authors.



Figure 8 - Scores of chemical elements in relation to the Principal Components PC1 and PC2

Source: The authors.

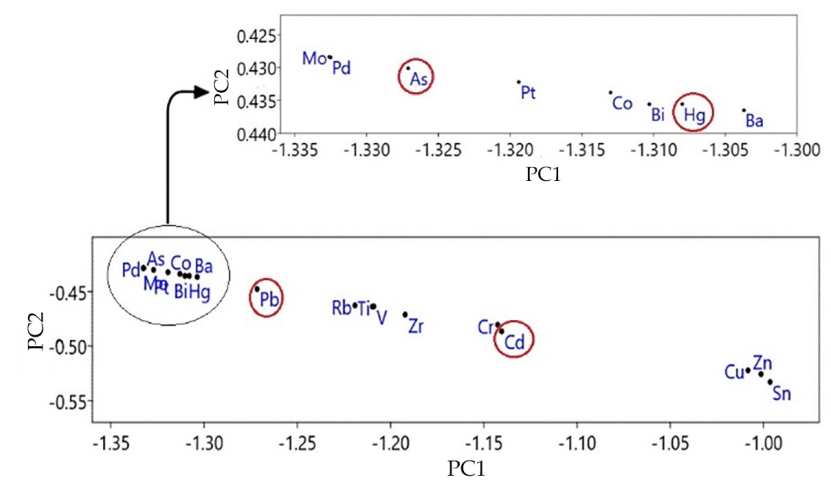

All the ground plants presented high K levels, however, the concentration of this element in all dried extracts was found to be low. This fact allowed the PCA analysis to separate the ground plants in one group and the extracts in another group. The $R$. purshiana presents close loadings both for the ground plant and for the dried extract in the PC2 component, and does not group with the other plants and/or extracts, the same occurring with the GuE (also not grouping) due to the mix of chemical elements that appear in proportions significantly different from those of the other plants.

A separate case is the $C$. scolymus L. whose composition of the detected elements differ little in the extract and in the ground plant, but which must have more similarity with the ground plants, and therefore it was placed in this group.

An analysis of the graphs displayed in Figures 8 and 9 leads to observation that the distribution of the chemical elements is very close to that presented in Figure 5, obtained by clustering analysis.

The chemical element that has the highest score in the PC2 component is Si whereas in the PC1 component one finds $\mathrm{K}$ followed by $\mathrm{Ca}, \mathrm{Cl}$ and $\mathrm{S}$, which therefore do not form a group (Figure 5). Figure 8 displays a subgroup formed by the elements $\mathrm{Ni}, \mathrm{P}, \mathrm{Fe}$ and $\mathrm{Mn}$, corroborating what was already observed in the analysis via clustering. 
Figure 9 - Detailed view of scores of chemical elements related to PC1 and PC2.

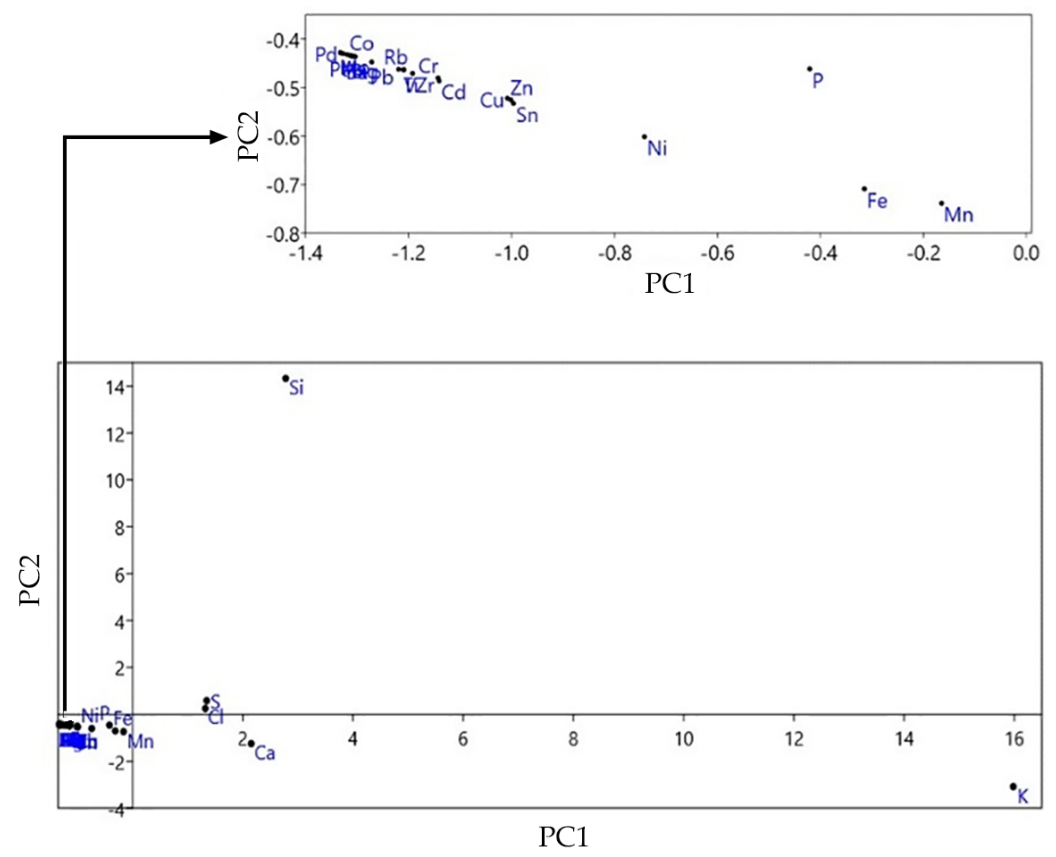

Source: The authors.

In our opinion, it seems easier to understand the behavior and correlations presented by ground plants, extracts and adjuvants through PCA analysis, and it appears to be clearer how chemical elements behave when we look at clustering analysis, but in the end, both techniques bring similar information about the problem, and both techniques of data analysis and representation complement each other, so it was important that both provided the same information.

\section{Conclusions}

The EDXRF technique used in the research effort entertained herein for identification and quantification of metal and nonmetal elements in herbal products, requires certification to be adopted by pharmacopoeias and other regulatory agencies, as a valid technique for elemental analysis. According to the Brazilian Pharmacopeia (ANVISA, 2010), the technique approved for quantification of heavy metals such as $\mathrm{As}, \mathrm{Cd}, \mathrm{Hg}$ and $\mathrm{Pb}$, besides a range of other elements like $\mathrm{Ir}, \mathrm{Mn}, \mathrm{Mo}, \mathrm{Ni}$, $\mathrm{Pd}, \mathrm{Pt}, \mathrm{Rh}, \mathrm{Ru}, \mathrm{V}, \mathrm{Cr}$ and $\mathrm{Cu}$, is the Atomic Absorption Spectrometry (AAS) (CALDAS; MACHADO, 2004). The AAS analytical method makes it possible to quantify each element present in the sample with a safety margin, considering the limits imposed by regulatory agencies (FERNÁNDEZ; LOBO; PEREIRO, 2019). However, the AAS technique requires the use of high cost equipment and the sample preparation and system calibration need to be performed by highly specialized technicians, making it unfeasible for use in most laboratories. On the other hand, with the advances in the electronics industry, it is now possible to find low cost X-ray Fluorescence equipment, which presents great precision and can be used for both qualitative and quantitative multi-elemental analyses, making it possible to determine the presence of elements from $\mathrm{Al}$ to $\mathrm{Fm}$, in concentrations ranging from $\mu \mathrm{g} \mathrm{g}^{-1}$ to thousands of $\mu \mathrm{g} \mathrm{g}^{-1}$ (in the present research work, one measured elements from $\mathrm{Si}$ to $\mathrm{Bi}$, in concentrations ranging from 2 to $856 \times 10^{3} \mu \mathrm{g} \mathrm{g}^{-1}$ ), in a quick and simultaneous fashion, indicating that the EDXRF technique, as demonstrated in this study, can be used to quantify practically all elements of interest in the pharmaceutical and food industries, within the limits established by regulatory agencies.

In the present work, practically all of the ground medicinal plants and their extracts presented contamination by heavy metals, with the levels of contamination for $\mathrm{As}$ and $\mathrm{Pb}$ of the herbal products analyzed, being in average below the limits recommended by the regulatory agencies; however, for the contaminants $\mathrm{Cd}$ and $\mathrm{Hg}$, in average, the values found were well above the recommended limits, as can be seen in the $\mathrm{Hg}$ contamination in the extract of $M$. officinalis L. We also show in this work, that part of the contamination found in the herbal products can come from the adjuvants/excipients used in 
the production process, since high levels of heavy metals like $\mathrm{Pb}$ in corn starch adjuvant and $\mathrm{Cd}$ in maltodextrin were detected. The producing process of the extracts from the ground plants presented low efficiency in the transferring process of the chemical elements present in the ground plants to the extracts, since the mean concentration of all elements, on average, were lower in the extracts than in the ground plants. The low efficiency in the extraction of the elements has the benefit of reducing the contamination by harmful elements to health, such as heavy metals.

We also show that it is possible, using multivariate data analysis, to understand how the chemical elements are correlated, and clearly show that plants, extracts and adjuvants also form clusters. As the herbal products consumed by the general population depends on the country, since the techniques of preparation of the herbal products, the specimens of plants used, the type of soil, fertilization, presence of pesticides, among others, in addition to popular beliefs regarding the uses of herbal products that are different from country to country. Although the exact location of the crop of the sampled plants has not been provided, there are strong correlations between several elements evidenced by the dendrogram $(>0.9)$ in the Figure 5, possibly indicating the same crop region, as a function of the absorption of these elements.

Considering the maxim that if a product is "natural" then it is good and therefore cannot be harmful to the health, there is the need for constantly monitoring the herbal products consumed by the local population and their respective production processes, in order to create safeguards for the safety of this population, since there are still gaps in the chemical composition of medicinal plants consumed in different countries and their effects on the health of the populations that consume them.

\section{Acknowledgments}

Project funding by Fundação de Amparo à Pesquisa do Estado de São Paulo (FAPESP, São Paulo, Brazil) (Refs. No. 2017/08674-1, 2018/06801-9, and Ref. No. 2018/05522-9). This work also received support from CNPq, National Council for Scientific and Technological Development Brazil (Refs. No. 306113/2014-7 and $308208 / 2017-0)$

\section{References}

ABDEL-TAWAB, M. Do we need plant food supplements? a critical examination of quality, safety, efficacy, and necessity for a new regulatory framework. Planta Medica, Uttar, v. 84, p. 372-393, 2018. DOI: https://doi.org/10.1055/s-0043-123764.

ALINA, M. et al. Heavy metals (mercury, arsenic, cadmium, plumbum) in selected marine fish and shellfish along the straits of malacca. International Food Research Journal, [London], v. 19, n. 1, p. 135-140, 2012. ISSN $1985-4668$

AL-OMARI, S. Determination of essential and toxic trace elements in ten herbal medicines using energy-dispersive XRF analysis. $X$-Ray Spectrometry, Chichester, v. 40, p. 31-36, 2011. DOI: https://doi.org/10.1002/xrs.1288.

ANVISA. Formulário de fitoterápicos farmacopeia brasileira. Brasília: Agência Nacional de Vigilância Sanitária, 2011. Available from: <http://portal.anvisa.gov.br /documents/33832/259456/Formulario_de_Fitoterapic os_da_Farmacopeia_Brasileira.pdf/>.Acess in: 3 jun. 2019.

ANVISA. Farmacopeia brasileira. 5th ed. Brasília: Agência Nacional de Vigilância Sanitária, 2010. v. 1.

ANVISA. Resolução - RDC n ${ }^{0}$ 42, de 29 de agosto de 2013. Regulamento Técnico MERCOSUL sobre Limites Máximos de Contaminantes Inorgânicos em Alimentos. Diário Oficial da União: seção 1, Brasília, DF, 30 ago. 2013.

AZEVEDO, J. C. S. Características bioativas, funcionais e efeito protetor do resíduo desidratado de camu-camu (Myrciaria dubia HBK (McVaugh)) sobre doenças degenerativas utilizando modelos in vivo C. elegans. 2015. Dissertation (Masters) - Universidade Federal do Rio Grande do Norte, Natal, 2015.

BARRETT, B. Medicinal properties of Echinacea: a critical review. Phytomedicine, Stuttgart, v. 10, n. 1, p. 66-86, 2003. DOI: https://doi.org/10.1078/094471103321648692.

BERNARD, A. Cadmium and its adverse effects on human health. The Indian Journal of Medical Research, Mumbai, v. 128, n. 4, p. 557-564, 2008.

CALDAS, E. D.; MACHADO. L. L. Cadmium, mercury and lead in medicinal herbs in Brazil. Food and Chemical Toxicology, Exeter, v. 42, p. 599-603, 2004. 
EKINCI, N.; EKINCI, R.; POLAT, R.; BUDAK, G. Analysis of trace elements in medicinal plants with energy dispersive X-ray fluorescence. Journal of Radioanalytical and Nuclear Chemistry, Lausanne, v. 260, p. 127-131, 2004. DOI: https://doi.org/10.1023/B:JRNC.0000027071.72742.ee.

ESTANAGEL, T. H. P. OLIVEIRA JUNIOR, J. M; BONVENTI JUNIOR, W; ARANHA, N.; CHAUD, M. V.;VILA, M. M. D. C.; BALCÃO, V. M.; YOSHIDA, V. M. H., Study of the elemental composition of plants and extracts of medicinal plants through $\mathrm{X}$ ray fluorescence. Journal of Physics, [S. l.], v. 1291, p. 012022, 2019. DOI: https://doi.org/doi:10.1088/17426596/1291/1/012022.

FAO - FOOD AND AGRICULTURE ORGANIZATION; WHO - WORLD HEALTH ORGANIZATION. Summary of Evaluation Performed by the Joint FAO/WHO Expert Committee on Food Additives (JECFA). Rome: JECFA, 2005. Available from: <http://www.fao.org/3/a-at877e.p df $>$. Acess in: 14 jun. 2019.

FERNÁNDEZ, B.; LOBO, L.; PEREIRO, R. Atomic absorpton spectrometry - fundamentals, instrumentation and capabilities. In: ENCYCLOPEDIA of Analytical Science. 3rd ed. Amsterdã: Elsevier, 2019. p 137-143.

FREITAS, C. A. S. et al. Acerola: produção, composição, aspectos nutricionais e produtos. Revista Brasileira de Agrociência, Pelotas, v. 12, n. 4, p. 395-400, 2006.

HAMMER, O.; HARPER, D. A. T.; RYAN, P. D. PAST: Paleontological statistics software package for education and data analysis. Palaeontologia Electronica, College Station, v. 4, n. 1, p. 9, 2001. Available from: <http://pala eo-electronica.org/2001_1/past/issue1_01.htm >. Acess in: 5 jun. 2019.

HENDLER, S. S. The Doctors' vitamin and mineral encyclopedia. New York: Simon and Schuster, 1991.

HERRERA-ESTRELLA, L. R.; GUEVARA-GARCIA, A. A. Heavy metal adaptation. In: ENCYCLOPEDIA OF LIFE SCIENCES. Chichester: John Wiley \& Sons, p. 1-9, 2009.

IVANOVA, J.; DJINGOVA, R.; KULEFF, I. Determination of some heavy and toxic elements in plants and soils with ED-XRF using americium-241 excitation source. Journal of Radioanalytical and $\mathrm{Nu}$ clear Chemistry, Lausanne, v. 238, p. 29-32, 1998. DOI: https://doi.org/10.1007/BF02385352.
JAIN, A. K.; DUBES, R. C. Algorithms for Clustering Data. USA: NJ, 1988.

JAISHANKAR, M. et al. Toxicity, mechanism and health effects of some heavy metals. Interdisciplinary Toxicology, Bratislava, v. 7, n. 2, p. 60-72, 2014.

LÄNGER, R.; STÖGER, E.; KUBELKA, W.; HELLIWELL, K. Quality standards for herbal drugs and herbal drug preparations - Appropriate or improvements necessary? Planta Medica, Uttar, v. 84, n. 6/7, p. 350-360, 2017.

LUIZ LUIZ, L. C. et al. Characterization of a group of medicinal herbs commercialized in Rio de Janeiro state through XRF spectroscopy. Demetra, Rio de Janeiro, v. 14, p. 1-14, 2019.

MARGUÍ, E.; QUERALT, I.; HIDALGO, M. Application of X-ray fluorescence spectrometry to determination and quantitation of metals in vegetal material. Analytical Chemistry, Amsterdam, v. 28, n. 3, p. 362-372, 2009.

MARGUÍ, E.; HIDALGO, M.; QUERALT, I. Multielemental fast analysis of vegetation samples by wavelength dispersive X-ray fluorescence spectrometry: Possibilities and drawbacks. Spectrochimica Acta Part B: Atomic Spectroscopy, Oxford, v. 60, n. 9/10, p. 1363-1372, 2005.

MCGLADDERY, C. et al. Elemental assessment of vegetation via portable X-ray fluorescence (PXRF) spectrometry. Journal of Environmental Management, Amsterdam, v. 210, p. 210-225, 2018. DOI: https://doi.org/10.1016/j.jenvman.2018.01.003.

MCKINNEY, W. Python for data analysis. Beijin: O'Reilly, 2013. Available from: <https://www.cin.ufpe .br/ embat/Python\%20for\%20Data\%20Analysis.pdf $>$. Acess in: 5 jun. 2019.

MELQUIADES, F. L.; GONÇALVES, G. W. P. S.; SILVA, W. D.; PARREIRA, P. S.; APPOLONI, C. R. Metal monitoring in igapó lakes in Londrina, Paraná, Brazil, using EDXRF methodology. Semina: Ciências Exatas e Tecnológicas, Londrina, v. 29, n. 2, p. 129-138, 2008.

MENNA JUNIOR, D.; BALCÃO; V. M. C. F.; CHAUD, M. V. ; VILA, M. M. D. C.; ARANHA, N.; YOSHIDA, V. M. H.; DE OLIVEIRA JUNIOR, J. M., Physicochemical evaluation of portland cement produced in Brazil via X-ray fluorescence and mechanical strength. Semina: Ciências Exatas e Tecnológicas, Londrina, v. 41, n. 1, p. 3-12, 2020. DOI: http://dx.doi.org/10.5433/1679-0375.2020v41np3. 
MOLARI, R.; ENDO, L. Y.; APPOLONI, C. R.; MELQUIADES, F. L.; PORTEZAN FILHO, O.; PARREIRA, P. S. Portable EDXRF and principal component analysis for inorganic element determination and provenance of eye shadows. Semina: Ciências Exatas e Tecnológicas, Londrina, v. 40, n. 2, p. 135-144, 2019. DOI: http://dx.doi.org/10.5433/16790375.2019v40n2p135.

NKANSAH, M. A.; HAYFORD, S. T.; BORQUAYE, L. S.; EPHRAIM, J. H. Heavy metal contents of some medicinal herbs from Kumasi, Ghana. Environmental Chemistry, Pollution \& Waste Management, Abingdon, v. 2, p. 1-8, 2016. DOI: https://doi.org/10.1080/23311843.2016.1234660.

OBIAJUNWA, E. I.; ADEBAJO, A. C.; OMOBUWAJO, O. R. Essential and trace element contents of some Nigerian medicinal plants. Journal of Radioanalytical and $\mathrm{Nu}$ clear Chemistry, Lausanne, v. 252, p. 473-476, 2002.

PREMIER LAB SUPPLY. PB-100 - Grinding Binding Additives. 2019. Available from: <https://www.premierl absupply.com/product-category/products-for-press-pel letizing/>. Acess in: 5 jun. 2019.

ICH - INTERNATIONAL COUNCIL FOR HARMONISATION. Q3D: guideline for elemental impurities. 2014. Available from: <https://www.ich.org/fileadmin/Publi c_Web_Site/ICH_Products/Guidelines/Quality/Q3D/Q 3D_Step_4.pdf >. Acess in: 6 jun. 2019.

SAAD, G. A.; LÉDA, P. H. O.; SÁ, I. M.; SEIXLACK, A. C. C. Fitoterapia contemporânea: tradição e ciência na prática clínica. 2nd ed. Rio de Janeiro: Guanabara Koogan, 2016.

SANTOS, A. F. J. et al. Multielement determination of macro and micro contents in medicinal plants and phytomedicines from Brazil by ICP OES. Journal of the Brazilian Chemical Society, São Paulo, v. 28, n. 2, p. 376-384, 2017. DOI: http://dx.doi.org/10.5935/01035053.20160187.

SANTOS, B. V.; OLIVEIRA JÚNIOR, J. M.; BONVENTI JÚNIOR, W.; HANAI-YOSHIDA, V. M. Assessment of chemical elements in cosmetics' eyeshodows by X-ray fluorescence and international nomenclature of cosmetic ingredients characterization. X-Ray Spectrometry, Chichester, p. 1-10, 2018. DOI: https://doi.org/10.1002/xrs.2835.
SARMA, H.; DEKA, S.; DEKA, H.; SAIKIA, R. R. Accumulation of Heavy Metals in Selected Medicinal Plants. Reviews of Environmental Contamination and Toxicology, New York, v. 214, p. 63-86, 2011. DOI: https://doi.org/10.1007/978-1-4614-0668-6_4.

SERENO, A. B.; GIBBERT, L.; BERTIN, R. L.; KRÜGER, C. C. H. Cultivo do Maná-Cubiu (Solanum sessiliflorum Dunal) no litoral do Paraná e sua contextualização com a segurança alimentar e nutricional. Divers@ Revista Eletrônica Interdisciplinar, Curitiba, v. 10, p. 123132, 2017.

SIMÕES, C. M. O. Farmacognosia da planta ao medicamento. 5th ed. Florianópolis: UFSC, 2003.

SMITH, A. H.; LINGAS, E. O.; RAHMAN, M. Contamination of drinking-water by arsenic in Bangladesh: A public health emergency. Bulletin of the World Health Organization, [S. 1.], 2000.

THEODORIDIS, S.; KOUTROUMBAS, K. Pattern Recognition. 4th ed. California: Academic Press, 2009.

TOLONEN, M. Vitamins and minerals in health and nutrition. Abington: Woodhead Publishing Limited, 1990.

USP - UNITED STATES PHARMACOPEIA. The United States Pharmacopeia (USP) Convention: revision and the national formulary. Rockville, USP, 2006.

WHO - WORLD HEALTH ORGANIZATION. Guidelines for assessing quality of herbal medicines with reference to contaminants and residue. Geneva: WHO Press, 2007.

WHO - WORLD HEALTH ORGANIZATION. Evaluation of certain food additives and contaminants. Geneva: WHO Press, 1978. Twenty-second Report of the Joint FAO/WHO Expert Committee on Food Additives. (Technical Report Series 631).

WHO - WORLD HEALTH ORGANIZATION. Evaluation of certain food additives and contaminants. Geneva: WHO Press, 1982. Twenty-sixth Report of the Joint FAO/WHO Expert Committee on Food Additives. (Technical Report Series 683)

WHO - WORLD HEALTH ORGANIZATION. Evaluation of certain food additives and contaminants. Geneva: WHO Press, 1989. Thirty-third Report of the Joint FAO/WHO Expert Committee on Food Additives. (Technical Report Series 776). 
WHO - WORLD HEALTH ORGANIZATION. Evaluation of certain food additives and contaminants. Geneva: WHO Press, 2000. Fifty-third Report of the Joint FAO/WHO Expert Committee on Food Additives. (Technical Report Series 896).
YAMABE, N.; KANG, K. S.; HUR, J. M.; YOKOZAWA, T. Matcha, a powdered green tea, ameliorates the progression of renal and hepatic damage in type 2 diabetic OLETF rats. Journal of Medicinal Food, Larchmont, v. 12, n. 4, p. 714-721, 2009. DOI: https://doi.org/10.1089/jmf.2008.1282. 